\title{
Penerapan Reciprocal Teaching Terhadap Kemampuan Berpikir Kreatif dan Self Concept Matematik Siswa SMP
}

\author{
Asep Ikin Sugandi \\ Prodi Pendidikan Matematika FPMS, IKIP Siliwangi Cimahi \\ asepikinsugandi@gmail.com
}

Received: 5 November 2019; Accepted: 30 November 2019; Published: 29 Desember 2019

\begin{abstract}
Abstrak
Tujuan penelitian ini adalah untuk menguji efektivitas penggunaan Reciprocal teaching dalam meningkatkan kemampuan berpikir kreatif matematik siswa. Metode dalam penelitian ini adalah metode kuasi eksperimen. Populasi dalam penelitian ini adalah seluruh siswa Sekolah Menengah Pertama Negeri di kota Cimahi, sedangkan sampel dipilih kelas VII dari salah satu Sekolah Menengah Pertama Negeri di kota Cimahi. Instrumen dalam penelitian ini adalah tes berbetuk soal uraian yang terdiri dari 5 pertanyaan untuk mengukur kemampuan berpikir kreatif dan non tes dalam bentuk skala Likert untuk mengukur self concept. Berdasarkan pengolahan data, didapat kesimpulan bahwa pendekatan reciprocal teaching lebih efektif daripada pendekatan biasa ditinjau dari kemampuan berpikir kreatif dan self concept siswa.
\end{abstract}

Kata kunci: Berpikir kreatif, konsep diri, reciprocal teaching

\begin{abstract}
The purpose of this study was to examine the effectiveness of using Reciprocal teaching in improving students' mathematical creative thinking abilities. The method in this study is a quasi-experimental method. The population in this study were all State Junior High School students in the city of Cimahi, while the sample was selected grade VII from one of the Public Middle Schools in the city of Cimahi. The instrument in this study was a test in the form of a question description consisting of 5 questions to measure the ability to think creatively and non-test in the form of a Likert scale to measure self concept. Based on data processing, it was concluded that the reciprocal teaching approach is more effective than the usual approach in terms of students' creative thinking abilities and self concept.
\end{abstract}

Keywords: Creative thinking, self-concept, reciprocal teaching 


\section{PENDAHULUAN}

Pada kenyataan sehari-hari manusia memerlukan kemampuan berpikir. Dengan berpikir individu dapat mengenali, memahami dan memecahkan masalah. Menurut Cotton (1991) menyebutkan berpikir kreatif adalah cara memandang atau melaksanakan sesuatu yang memiliki ciri empat unsur yaitu (1) kelacaran (menyatakan berbagai ide). (2) kelenturan (kemampuan untuk memnadang ke arah depan dengan mudah), (3) keaslian (menyatakan sesuatu yang baru) dan (4) Elaborasi (menyatakan sesuatu berdasarkan ide-ide baru.

Menurut Munandar (2009) dan Chua (2004) indikator berpikir kreatif meliputi: (a) fluency atau berpikir lancar, hal ini dicirikan dengan kemampuan mencetuskan berbagai ide, menyelesaian persoalan dan pertanyaan. (b) flexibility atau berpikir luwes, yaitu kemampuan menemukan berbagai jawaban atau pertanyaan yang beragam. (c) originality atau berpikir orisinil, yaitu kemampuan melahirkan berbagai gagasan terbaru dan bersifat unik (d) elaboration yaitu kemampuan megembangkan dan memperbanyak suatu ide atau hasil.

Pada dasarnya berpikir kreatif merupakan kemampuan esensial yang perlu dikuasai oleh siswa, alasan yang melatar belakangi ungkapan diatas adalah menurut Hendriana, Rohaeti, \& Sumarmo (2017) bahwa berpikir kreatif sejalan dengan visi matematika antara lain : melatih berpikir yang logis, sistematik, kritis, kreatif dan cermat serta berpikir objektif dan bersifat terbuka dalam menghadapi masalah pada kehidupan sehar-hari. Lebih lanjut Hendriana, Rohaeti, \& Sumarmo (2017) menyatakan bahwa secara umum dan di pandang dari pembelajaran matematika bahwa berpikir kreatif adalah keterampilan yang penting dimiliki siswa untuk menyongsong perkembangan IPTEKS yang makin pesat serta menghadapi tantangan, tuntutan serta persaingan internasional yang makin ketat.
Namun fakta dilapangan menyatakan masih rendahnya berpikir kreatif, ini sesuai penelitian Fardah (2012) yang menyatakan pada umumnya di Indonesia pada sekolah menengah menunjukkan berpikir siswa masih rendah. Salah satu faktor penghambat berpikir kreatif adalah tahap berpikir. Putra (2014) menyatakan bahwa $85.71 \%$ siswa di salah satu sekolah menengah berada di tahap berpikir konkrit, hal ini mengakibatkan siswa mengalami kesulitan memahami gagasan matematika yang bersifat abstrak. Disamping itu, proses yang menghambat berpikir kreatif siswa adalah pengalaman belajar. (Akmalia, Pujiastuti, \& Setiani, 2016). Sedikitnya pengalaman siswa dalam kegiatan belajar, mengakibatkan rendahnya berpikir kreatif.

Disamping aspek kognitif perlu juga dimiliki siswa adalah aspek afektif. Salah satu aspek afektif yang penting dimiliki siswa adalah Self concept (Konsep diri). Menurut Desmita (2010) menyatakan bahwa self concept adalah pemahaman tentang diri atau suatu konsep mengenai diri yang mereflesikan suatu gambaran penilaian diri. Lebih lanjut Agustiani (2009) self concept bukanlah faktor keturunan, melainkan berkembang dari yang berkelanjutan dan dibedakan pengalaman.

Pentingnya kepemilikan self-concept dinyatakan oleh Liu (2009) bahwa Siswa dengan self concept akademik yang kurang positif cenderung kurang motivasi belajar, yang menyebabkan kinerja akademik yang buruk. Disamping itu menurut Leonard \& US (2010) mengatakan bahwa ada beberpa faktor yang mempengaruhi hasil belajar matematika siswa, antara lain sikap siswa pada matematika, yaitu konsep diri (self-concept) dan kecemasan yang dialami siswa pada pembelajaran matematika. Dengan demikian betapa pentingnya kepemilikan self concept terhadap hasil dan motivasi belajar siswa dalam matematika.

Berdasarkan beberapa pengertian konsep diri, Hendriana, Rohaeti, \& Sumarmo (2017) : merangkum beberapa indikator sebagai berikut 
a). Kesungguhan, ketertarikan,, berminat, menunjukkan keinginan, keberanian, keuletan, kesungguhan, perhatian dalam pembelajaran matematika, b). dapat mengidentifikasi kekuatan serta kelemahan pribadi dalam matenatika, c). percaya akan kemampuan pribadi dan sukses menunaikan tugas, d) bekerjasama dan bersikap toleran pada orang lain, e). bersikap memaapkan kesalahan dan dapat menghargai pandangan orang lain, f) berperilaku sosial menyatakan kemampuan untuk berkomunikasi dan tahu menempatkan diri, dan g). menguasai fungsi dan kesukaan belajar matematika. Dalam usaha menumbuhkembangkan kemampuan dalam berpikir kreatif serta self concept maka diperlukan suatu pendekatan yang memotivasi siswa agar belajar aktif dalam rangka meningkatkan berpikir kreatif serta self consept. Salah satu pembelajaran yang diduga sanggup meningkatkan berpikir kreatif dan self concept adalah pendekatan reciprocal. Arends (1997) mendefinisikan reciprocal teaching sebagai suatu cara yang dipersiapakan untuk membimbing siswa tentang pendektan kognitif dan mendukung siswa dalam menguasai konsep pembelajaran secara baik. Trianto (2009) juga mendefinisikan bahwa reciprocal adalah suatu pendekatan konstruktivis akan strategi-strategi belajar siswa yang berdasar pada dasar-dasar pengajuan pertanyaan melalui belajar mandiri sehingga siswa mampu menjelaskan hasil temuan kepada orang lain serta dapat meningkatkan belajar mandiri siswa.

Menurut Borich (1988) mengatakan pendekatan reciprocal adalah pendekatan pembelajaran kooperatif yang dapat membuat diskusi menjadi kemahiran belajar yang kreatif dan mandiri. Kegiatan diskusi pada pembelajaran reciprocal terdiri dari : memprediksi jawaban dan pertanyaan, merangkum materi, dan membuat klarifikasi. Dengan kegiatan ini diharapkan siswa mampu mengkonstruksi pengetahuannya dengan cara mandiri dan terarah sehingga diharapkan pengetahuan tersebut dapat tersimpan dalam ingatan siswa lebih lama.
Dari uraian tersebut dapat disimpulkan reciprocal teaching adalah suatu pendekatan yang bersifat konstruktivis bertujuan agar siswa mampu mengusai pembelajaran dengan baik dengan menggunakan empat pendekatan kognitif, yaitu mengklarifikasi, memprediksi, membuat pertanyaan, dan merangkum materi yang memfokuskan pada kerjasama sesama siswa pada kelompok kecil dan dalam kelompok besar yang melinbatkan guru dengan siswa.

Berdasarkan uraian diatas maka rumusan masalah penelitian ini sebagai berikut apakah penerapan pembelajaran reciprocal lebih efektif dari pendektan biasa ditinjau dari berpikir kreatif dan self concept.

\section{METODE}

Metode dalam penelitian ini adalah metode kuasi eksperimen karena adanya manipulasi perlakuan dan penentuan sampel dipilih secara tidak acak, penelitian ini memerlukan dua kelas, kelas yang satu, kelas eksperimen, yaitu kelas yang diberi pembelajaran menggunakan pendekatan reciprocal teaching serta kelas yang lain adalah kelas kontrol, yang diberi pembelajaran dengan pembelajaran biasa. Sebelum maupun sesudah perlakuan kedua kelas diberi tes yang sama. Adapun disain penelitiannya adalah pre dan post tes kelompok kontrol disain dan digambarkan berikut ini :

\section{Tabel 1 Desain Penelitian}

\begin{tabular}{ccc}
\hline $\mathrm{O}$ & $\mathrm{X}$ & $\mathrm{O}$ \\
\hline $\mathrm{O}$ & & $\mathrm{O}$ \\
\hline
\end{tabular}

Keterangan

$\mathrm{O}=$ Pre tes/Pos tes

$\mathrm{X}=$ Perlakuan berupa pemberian pembelajaran dengan pendektan Reciprocal teaching

--- = Pengambilan sampel secara tidak acak subyek 
Populasi penelitian ini adalah setiap siswa SMP Negeri kelas VII yang berada di Cimahi, sedangkan sampelnya ditentukan dua kelas secara acak dari salah satu SMP di Cimahi. Instrumen penelitian ini berbentuk tes dengan soal urain sebanyak 5 soal untuk mengukur kemampuan berpikir kreatif serta non tes berbentuk skala Likert sebanyak 30 pernyataan. Untuk memenuhi standar soal yang baik, maka soal dikonsultasikan dengan dosen senior IKIP Siliwangi dalam rangka mendapatkan validitas isi, sedangkan untuk menentukan validitas kontruks maka soal diujicobakan dahulu kemudian ditentukan nilai validitas dan reliabilitas. Dari hasil perhitungan didapat nilai validitas sebesar 0,75, 081, 085, 076 dan 0,87 sedangkan reliabilita didapat sebesar 0,78 dan dikatergorikan tinggi. Teknik pengolahan data dilakukan dengan uji normalitas, homogenitas dan uji perbedaan dua rata-rata.
Adapun prosedur penelitian ini dibagi menjadi tiga tahap, yaitu (1) tahap perencanaan, meliputi studi pustaka mengenai berpikir kreatif, self concept, dan pendekatan reciprocal teaching, membuat RPP, bahn ajar serta LKS, membuat instrumen penelitian dalam rangka menilai berpikir kreatif, self concept dan menentukan sampel penelitian, (2) tahap pelaksanaan, meliputi : memberikan pre tes pada dua kelas, memberikan perlakuan kepada dua kelas, kelas eksperimen yang diberi pendekatan reciprocal teacing sedangkan untuk kelas kontrol diberi pendekatan biasa, (3) tahap evaluasi, meliputi pemberian tes akhir, pengolahan data dan pembuatan laporan akhir.

\section{HASIL DAN PEMBAHASAN}

Berdasarkan hasil pengolahan data kuantitatif terhadap hasil pre tes, pos tes dan N-gain berpikir kreatif, didapat hasil yang pada Tabel 2 berikut :

Tabel 2

Hasil pengolahan kuantitatif terhadap hasil pre tes, pos tes dan N-gain berpikir kreatif

\begin{tabular}{ccccccccc}
\hline Nilai & \multicolumn{9}{c}{ Eksperimen } & \multicolumn{3}{c}{ Kontrol } \\
\cline { 2 - 8 } & $\mathrm{N}$ & $\bar{x}$ & $\mathrm{~s}$ & $\%$ & $\mathrm{~N}$ & $\bar{x}$ & $\mathrm{~s}$ & $\%$ \\
\hline Pre-tes & 30 & 4.26 & 1.53 & 21,30 & 30 & 3.92 & 1,29 & $19,60 \%$ \\
Pos-tes & 30 & 10,98 & 2,93 & $54,90 \%$ & 30 & 6,79 & 2,30 & $33,95 \%$ \\
N-Gain & 30 & 0,43 & 0,18 & $43 \%$ & 30 & 0,18 & 0,13 & $18 \%$ \\
\hline \multicolumn{1}{c}{ Skor Maksimum Ideal = 20 } & \\
\hline
\end{tabular}

Dari tabel 2 di dapat hasil pre tes, untuk ratarata berpikir kreatif untuk kelas yang diberi reciprocal teaching sebesar 4,26 sedangkan untuk kelas yang diberi pendekatan biasa didapat rata-rata sebesar 3,92, selisih rata-rata kedua kelas sebesar 0,34 dan selisih ini sangat kecil jika dibanding nilai SMI sebesar 20, maka dapat diduga bahwa tidak terdapat perbedaan kemampuan berpikir kreatif matematis siswa yang diberi pendekatan reciprocal teaching dengan pendektan biasa. Untuk data pos tes, didapat rata-rata berpikir kreatif untuk kelas yang diberi pendekatan reciprocal teaching sebesar 10,98 sedangkan untuk kelas yang pembelajarannya menggunakan pendekatan biasa didapat rata-rata sebesar 6,79 selisih rata- rata kedua kelas tersebut sebesar 4,19 dan selisih ini cukup besar jika diandingkan dengan nilai SMI sebesar 20, maka dapat diduga pencapaian kemampuan berpikir kreatif matematis siswa yang yang diberi pendekatan reciprocal teaching lebih baik daripada pendekatan biasa.

Selanjutnya hasil N-gain, didapat rata-rata untuk berpikir kreatif untuk kelas yang diberi pendekatan reciprocal teaching sebesar 0,43 sedangkan untuk kelas yang diberi pendekatan biasa didapat rata-rata sebesar 0,13 selisih ratarata kedua kelas tersebut sebesar 0,3 dan selisih ini cukup besar jika diandingkan dengan nilai SMI sebesar 1, maka dapat diduga peningkatan 
kemampuan berpikir kreatif matematis siswa yang diberi pendekatan reciprocal teaching lebih baik daripada pendektan biasa.

Untuk menunjukan bahwa hasil statistik deskriptif itu benar, maka perlu digunakan uji statistik inferensial, sebelum menguji hipotesis penelitian terlebih dahulu diperlukan uji prasyarat yaitu uji normalitas dan uji homogenitas.
Adapun untuk menguji normalitas data pre-tes, pos-tes dan N-gain digunakan uji KolmogorovSmirnov dengan taraf kepercayaan 95\%. Dari pengolahan data didapat hasil pengujian normalitas nilai pre-tes, pos-tes dan N-gain sebagai berikut:

\section{Hasil Pengujian normalitas terhadap pre-tes, pos-tes dan $\mathrm{N}$-gain Kemampuan berpikir matematis siswa}

\begin{tabular}{ccc|c|c}
\hline \multirow{2}{*}{ TES } & \multirow{2}{*}{ KELAS } & \multicolumn{3}{c}{ Kolmogorov-Smirnov } \\
\cline { 3 - 5 } & & $\begin{array}{c}\text { Statisti } \\
\mathrm{c}\end{array}$ & $\mathrm{df}$ & Sig. \\
\hline \multirow{2}{*}{ PRETES } & EKSPERIMEN & 0.119 & 30 & $.0200^{*}$ \\
& KONTROL & 0.087 & 30 & $0.200^{*}$ \\
\hline \multirow{2}{*}{ POSTES } & EKSPERIMEN & 0.098 & 30 & $0.200^{*}$ \\
& KONTROL & 0.132 & 30 & 0.196 \\
\hline \multirow{2}{*}{ NGAIN } & EKSPERIMEN & 0.111 & 30 & $0.200^{*}$ \\
& KONTROL & 0.110 & 30 & $0.200^{*}$ \\
\hline
\end{tabular}

Berdasarkat tabel 3, untuk pre tes, didapat nilai sign untuk kelas eksperimen dan kontrol berturut-turut sebesar o,200 dan 0,196, karena nilai sign. untuk kedua kelas lebih besar dari o,05, maka disimpulkna bahwa data hasil pre tes untuk kelas eksperimen maupun kontrol berdistribusi normal, untuk nilai pos tes , didapat nilai sign untuk kelas eksperimen dan kontrol berturut-turut sebesar 0,200 dan o,200, karena nilai sign. untu kedua kelas lebih besar dari 0,05, maka disimpulkan bahwa data hasil pos- tes untuk kelas eksperimen maupun kelas kontrol berdistribusi normal, sedangkan untuk N-gain, didapat nilai sign untuk kelas eksperimen dan kelas kontrol berturut-turut sebesar 0,200 dan 0,200, karena nilai sign. untuk kedua kelas lebih besar dari o,05, maka disimpulkan bahwa data hasil N-gain untuk kelas eksperimen maupun kelas kontrol berdistribusi normal.

Untuk selanjutnya, karena baik data pre-tes, pos-tes dan $\mathrm{N}$-gain berdistribusi normal, maka dilanjutkan dengan uji homogeninitas menggunakan uji lavene. Berdasarkan pengolahan data terhadap pre-tes, pos-tes dan $\mathrm{N}$-gain didapat hasil uji homogenitas sebagai berikut :

Tabel 4

Hasil Uji homogenitas terhadap pre-tes, pos-tes dan N-gain berpikir kreatif matematika siswa

\begin{tabular}{cccc}
\hline TES & F & Sig. & Keterangan \\
\hline PRETES & 1.043 & 0.311 & Varians kedua kelompok Homogen \\
POSTES & 3.640 & 0.061 & Varians kedua kelompok Homogen \\
NGAIN & 4.521 & 0.038 & Varians kedua kelompok TidakHomogen \\
\hline
\end{tabular}


Berdasarkan hasil pada tabel 4, didapat nilai signifikasi untuk pre dan pos-tes berturut-turut sebesar 0,311 dan 0,061, karena nilai signifikasi lebih besar dari 0,05 maka disimpulkan data untuk pre dan pos-tes memiliki varians yang homogen untuk kedua kelompok, sedangkan untuk N-gain didapat nilai signifikasi sebesar 0,038 , karena nilai signifikasi lebih kecil dari 0,05 maka data untuk N- gain memiliki varians tidak homogen untuk kedua kelompok.

Untuk selanjutnya digunakan uji t untuk pre-dan postes. Sedangkan unuk N-gain digunakan uji t', berdasarkan pada pengolahan data terhadap pre-tes, pos-tes dan $\mathrm{N}$-gain didapat hasil sebagai berikut:

\section{Tabel 5}

Hasil Uji t dan t' terhadap pre-tes, pos-tes dan N-gain berpikir kreatif matematis Siswa

\begin{tabular}{c|c|c|c}
\hline TES & $\mathrm{t} / \mathrm{t}^{\prime}$ & $\mathrm{df}$ & Sig. (2-tailed) \\
\hline PRE-TES & 0.910 & 58 & 0.367 \\
\hline POS-TES & 6.160 & 58 & 0.000 \\
\hline N-GAIN & 6.254 & 53.158 & 0.000 \\
\hline
\end{tabular}

Dari tabel 5 didapat nilai pre-tes sebesar 0,67, karena nilai signifikasi lebih besar dari 0,05, maka disimpulkan bahwa tidak terdapat perbedaan kemamapuan awal berpikir kreatif siswa antara yang diberi pendektan reciprocal teaching dengan yang diberi pendekatan biasa untuk pos tes didapat nilai signifikasi 2 tailed sebesar o,oo, sedangkan nilai signisikasi untuk 1 tailed Uyanto (2009) adalah sebesar 0,00/2 = o,oo, karena nilai signifikasi lebih kecil dari o,05, maka disimpulkan pencapaian berpikir kreatif matematis siswa yang diberi pendekatan reciprocal teaching lebih baik dari pendekatan biasa, sedangkan untuk N-gain didapat nilai signifikasi untuk 2 tailed sebesar 0,00, untuk nilai signifikasi 1 tailed Uyanto (2009) adalah sebesar $0,00 / 2=0,00$, karena nilai signifikasi lebih kecil dari 0,05, maka disimpulkan peningkatan berpikir kreatif matematis siswa yang diberi pendekatan reciprocal teaching lebih baik dari pendekatan biasa

Untuk selanjutnya disajikan hasil pos-skala untuk mengukur self concept, berdasarkan pengolahan data terhadap skala sikap didapat hasil sebagai berikut :

Tabel 6

Hasil pengolahan data angket self concept

\begin{tabular}{ccccccccc}
\hline Nilai & \multicolumn{4}{c}{ Eksperimen } & \multicolumn{3}{c}{ Kontrol } \\
\cline { 2 - 8 } & $\mathrm{N}$ & $\bar{x}$ & $\mathrm{~S}$ & $\%$ & $\mathrm{~N}$ & $\bar{x}$ & $\mathrm{~s}$ & $\%$ \\
\hline Pos-tes & 30 & 110.33 & $\begin{array}{c}9.62 \\
\text { S. }\end{array}$ & $\begin{array}{c}91.94 \\
\text { Skor Maksimum Ideal = 120 }\end{array}$ & 303.20 & 13.86 & $86 \%$ \\
\hline
\end{tabular}

Dari tabel 6 didapat hasil nilai rata-rata pos skala untuk kelas eksperimen sebesar 110,33, kelas kontrol sebesar 103,20, selisih kedua ratarata kelas tersebut sebesar 7.13, selisih kedua rata-rata ini cukup besar sehingga dapat diduga self concept siswa yang diberi pendekatan reciprocal teaching lebih baik dari pada pendektan biasa, Namun hasil ini perlu diuji kebenarannya dengan menggunakan statistik inferensial, sebelum menguji hipotesis penelitian terlebih dahulu diperlukan uji prasyarat yaitu pengujian normalitas dan homogenitas. Adapun untuk menguji normalitas data pos-skala self concept digunakan uji Kolmogorov-Smirnov dengan taraf kepercayaan 95\%. Dari pengolahan data didapat hasil pengujian normalitas nilai posskala self concept seperti di bawah ini : 
Tabel 7

Hasil pengolahan normalitas data skala self concept

\begin{tabular}{ccc|c|c}
\hline \multirow{2}{*}{ SKALA } & \multirow{2}{*}{ KELAS } & \multicolumn{3}{c}{ Kolmogorov-Smirnov } \\
\cline { 3 - 5 } & & Statistic & df & Sig. \\
\hline POS- & EKSPERIMEN & 0.119 & 30 & $.0200^{*}$ \\
SKALA & KONTROL & 0.087 & 30 & $0^{*} 200^{*}$ \\
\hline
\end{tabular}

Dari tabel 7 didapat nilai signifikasi baik untuk kelas eksperimen maupun kontrol sebesar 0,200 , karena nilai signifikasi lebih besar dari 0,05 maka disimpulkan data pos-skala self concept siswa baik untuk kelas eksperimen maupun kontrol keduanya berdistribusi normal. Langkah selanjutnnya dilakukan uji homogenitas dua varians menggunakan uji Lavene.

Berdasarkan pengolahan data terhadap hasil skala self concept siswa didapat hasil sebagai berikut

Tabel 8

Hasil pengolahan homogenitas data skala self concept

\begin{tabular}{cccc}
\hline SKALA & F & Sig. & Keterangan \\
\hline POS-SKALA & 1,122 & 0,294 & Varians kedua kelompok Homogen
\end{tabular}

Dari tabel 8 didapat nilai signifikasi sebesar 0,294, karena nilai signifikasi lebih besar dari o,05.maka disimpulkan varians kedua kelompok homogen.
Untuk selanjutnya digunakan uji pos-skala self concept, berdasarkan pengolahan data terhadap pos-skala self concept didapat hasil sebagai berikut:

Tabel 9

Hasil Uji t terhadap pos-skala self concept

\begin{tabular}{c|c|c|c}
\hline SKALA & $\mathrm{t}$ & $\mathrm{df}$ & Sig. (2-tailed) \\
\hline POS-SKALA & 2.32 & 58 & 0,024 \\
\hline
\end{tabular}

Dari tabel 9 didapat nilai signifikasi untuk 2 tailed sebesar 0,024. Sedangkan untuk 1 tailed Uyanto (2009) didapat 0,024/2 =0,012, karena nilai signifikasi lebih kecil dari 0,05 maka disimpulkan bahwa self concept siswa yang diberi pendekatan reciprocal teaching lebih baik dari pada pendekatan biasa.

Berdasarkan pengolahan data yang telah dilakukan disimpulkan bahwa pendekatan reciprocal teaching lebih efektif dari pada pendekatan biasa diitnjau dari pencapaian dan peningkatan berpikir kreatif. Hal tersebut sejalan penelitian Rachmayani (2014) menyatakan pembelajaran reciprocal teaching lebih efektif dari pembelajaran langsung ditinjau dari kemampuan komunikasi matematik siswa. Penelitian tersebut sejalan penelitian Awaliah \& Idris (2015) yang mengatakan pembelajaran reciprocal teaching memberikan pengaruh yang lebih signifikan dari pendekatan langsung ditinjau dari hasil belajar matematika pada siswa MTS Negeri kelas VIII. Disamping itu penelitian tersebut sejalan dengan Novianti, Zubaidah, \& Hamdani (2017) menyatakan bahwa terdapat perbedaan berpikir kreatif siswa yang diberi Pendekatan 
Open-Ended dengan yang diberi pendekatan konvensional pada materi tabung dan kerucut di kelas IX SMPN 1 Sungai Raya.

Adapun yang menyebabkan reciprocal teaching lebih efektif dari pada pendekatan biasa ditinjau dari berpikir kreatif matematis, hal ini disebabkan oleh langkah-langkah pembelajaran pada reciprocal teaching sejalan dengan indikator pada berpikir kreatif, diantaranya : Langkah merangkum (Summarizing), pada langkah tersebut siswa mempelajari materi yang disajikan oleh guru kemudian mencatat apa yang penting, pada tahap tersebut siswa bertugas untuk menjelaskan pikiran utama pada bacaan tersebut dengan bahasanya sendiri, sehingga diperlukan kemampuan untuk menyatakan hal-hal terbaru dan unik yang memiliki perbedaan dengan biasanya serta memikirkan cara yang tidak lazim, hal ini sesuasi dengan indikator berpikir kreatif : keaslian (orginalitas). Pada langkah menyusun pertanyaan (Questioning), pada langkah tersebut siswa bertugas membantu anggota kelompok untuk bertanya dan menjawab pertanyaan tentang bacaan yang disajikan oleh guru dan mengingatkan kelompok untuk menggunakan berbagai pertanyaan dari level rendah sampai level tinggi, hal tersebut sejalan indikator berpikir kreatif : kelenturan. Tahap selanjutnya adalah tahap menjelaskan (Clarifying), pada langkah tersebut siswa bertugas untuk menerangkan kembali ilmu yang telah diperolehnya agar semua siswa benar-benar telah menguasai konsep yang sudah dipelajarinya. Siswa juga bertugas membantu anggota kelompoknya menemukan bagian-bagian yang tidak jelas dan menetapkan model-model atau masukan untuk melakukan variasi dalam hal memecahkan persoalan yang dihadapi, hal tersebut sejalan indikator kelancaran, dan langkah yang terakhir adalah memprediksi (predicting), pada langkah tersebut siswa bertugas membantu anggota kelompoknya untuk menghubungkan bagianbagian dari bacaan dengan menyajikan prediksi agar siswa lainnya dapat memperbanyak dan menguraikan suatu ide atau produk, hal tersebut sejalan indikator berpikir kreatif : elaborasi. Berdasarkan uraian yang telah disampaikan, jelaslah bahwa terdapat kaitan yang cukup kuat antara langkah-langkah pendekatan reciprocal teaching dengan indikator berpikir kreatif.

Berdasarkan hasil pengolahan data yang telah diuraikan bahwa pendekatan reciprocal teaching lebih efektif dibandingkan pendekatan biasa ditinjau dari segi self conceft siswa. Hal tersebut sejalan penelitian Widayati, Suyono, \& Rahayu (2018) menyatakan pembelajaran discovery terbimbing lebih efektif dari dari inkuiri terbimbing dan konvensioanal ditinjau dari self concept. peserta didik SMP kelas VII. Hal tersebut sejalan juga dengan penelitian Rahmawati, Priatna, \& Nurjanah (2018) menyatakan bahwa pendekatan saintifik lebih efektif dibandingkan pendekatan biasa ditinjau dari dari kemampuan koneksi dan self concept Lebih baiknya pembelajaran menggunakan pembelajaran reciprocal terhadap self concept dibandingkan dengan pembelajaran biasa adalah karena dalam pembelajaran reciprocal siswa dituntut agar mampu berkolaborasi dengan teman sekelompoknya mendiskusikan berbagai masalah dan kegiatan yang relevan dengan topik pembelajaran, membangun ideide baru serta membuat dugaan untuk dapat menyelesaikan permasalahan matematika. Dalam tahap tersebut, siswa dituntut agar dapat percaya diri mengungkapkan apa yang dipikirkannya mengenai definisi atau konsep yang diajarkan. Kemudian, siswa diberikan kesempatan mengkomunikasikan hasil- hasil diskusinya, Hal sejalan pendapat Sumartini (2015) menyatakan bahwa kolaborasi bersama teman sekelompok dalam hal menggabungkan ide-ide atau dugaan dari konsep atau definisi yang dipelajari agar dapat menuntun siswa untuk menumbuhkan self-concept positif siswa.

\section{KESIMPULAN}

Berdasarkan pengolahan data maka disimpulkan bahwa: pendekatan reciprocal teaching lebih efektif dibandingkan pendekatan biasa ditinjau dari berpikir kreatif dan self 
concept siswa. Hal ini dapat dilihat dari nilai rata-rata kemampuan berpikir kreatif dan selfconcept matematik pada pos tes dan $\mathrm{N}$-gain yang pembelajarannya menggunakan pendekatan reciprocal teaching lebih tinggi dibandingkan pendekatan biasa.

\section{REFERENSI}

Agustiani, H. (2009). Psikologi Perkembangan (Pendekatan Ekologi Kaitannya dengan Konsep Diri dan Penyesuaian Diri pada Remaja). Bandung: Refika Aditama.

Akmalia, N. N., Pujiastuti, H., \& Setiani, Y. (2016). Identifikasi Tahap Berpikir Kreatif Matematis melalui Penerapan Model Problem Based Learning dengan Tugas Pengajuan Masalah. JPPM (Jurnal Penelitian dan Pembelajaran Matematika), 9(2).

Arends, R. (1997). Classroom Instruction and Management. McGraw-Hill Companies.

Awaliah, R., \& Idris, R. (2015). Pengaruh Penggunaan Model Reciprocal Teaching terhadap Hasil Belajar Matematika Siswa Kelas VIII MTSN Balang-Balang Kecamatan Bontomarannu Kabupaten Gowa. MaPan: Jurnal Matematika Dan Pembelajaran, 3(1), 59-72.

Borich, G. D. (1988). Effective Teaching Methods. Pearson Education India.

Chua, Y. P. (2004). Creative and Critical Thinking Styles. Universiti Putra Malaysia Press.

Cotton, K. (1991). Teaching Thinking Skills. Northwest Regional Educational Laboratory, School Improvement Program.

Desmita. (2010). Perkembangan Psikologi (4th ed.). Bandung: PT. Remaja Rosdakarya.

Fardah, D. K. (2012). Analisis Proses dan Kemampuan Berpikir Kreatif Siswa dalam Matematika Melalui Tugas Open-Ended. Kreano, Jurnal Matematika KreatifInovatif, 3(2), 91-99.
Hendriana, H., Rohaeti, E. E., \& Sumarmo, U. (2017). Hard Skills dan Soft Skills Matematik Siswa (I). Bandung: Refika Aditama.

Leonard, L., \& US, S. (2010). Pengaruh Konsep Diri, Sikap Siswa pada Matematika, dan Kecemasan Siswa terhadap Hasil Belajar Matematika.

Liu, H. J. (2009). Exploring changes in academic self-concept in ability-grouped English classes. Chang Gung Journal of Humanities and Social Sciences, 2(2), 411432.

Munandar, U. (2009). Kreatifitas Pengembangan Anak Berbakat. Jakarta: Rineka Cipta.

Novianti, M., Zubaidah, R., \& Hamdani. (2017). Pengaruh Pendekatan Open-Ended terhadap Kemampuan Berpikir Kreatif Siswa Sekolah Menengah Pertama. Jurnal Pendidikan Dan Pembelajaran Khatulistiwa, 6(2), 1-10.

Putra, H. D. (2014). Tahap Perkembangan Kognitif Matematika Siswa MTs Asy Syifa Kelas IX Berdasarkan Teori Piaget. Prosiding Seminar Nasional Pendidikan Matematika, 2, 224-230.

Rachmayani, D. (2014). Penerapan Pembelajaran Reciprocal Teaching untuk Meningkatkan Kemampuan Komunikasi Matematis dan Kemandirian Belajar Matematika Siswa. JUDIKA (Jurnal Pendidikan Unsika), 2(1).

Rahmawati, Y., Priatna, N., \& Nurjanah, N. (2018). Meningkatkan Kemampuan Koneksi Matematis dan Self-Concept Siswa Melalui Pendekatan Saintifik pada Materi Trigonometri. JMPM: Jurnal Matematika Dan Pendidikan Matematika, 3(2), 108-122.

Sumartini, T. S. (2015). Mengembangkan Self Concept Siswa melalui Model Pembelajaran Concept Attainment. Mosharafa: Jurnal Pendidikan Matematika, 4(2), 48-57. 
Trianto, M. P. (2009). Mendesain Model Pembelajaran Inovatif-Progresif. Jakarta: Kencana.

Uyanto, S. S. (2009). Pedoman Analisis Data dengan SPSS. Yogyakarta: Graha Ilmu.

Widayati, W., Suyono, S., \& Rahayu, W. (2018). Pengaruh Model Pembelajaran Berbasis
Penemuan terhadap Kemampuan Berpikir Kritis Matematis dan Self Concept dengan Mengontrol Kemampuan Awal Peserta Didik Kelas VII SMP. JPPM (Jurnal Penelitian dan Pembelajaran Matematika), 11(1). 